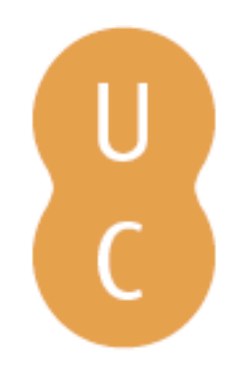

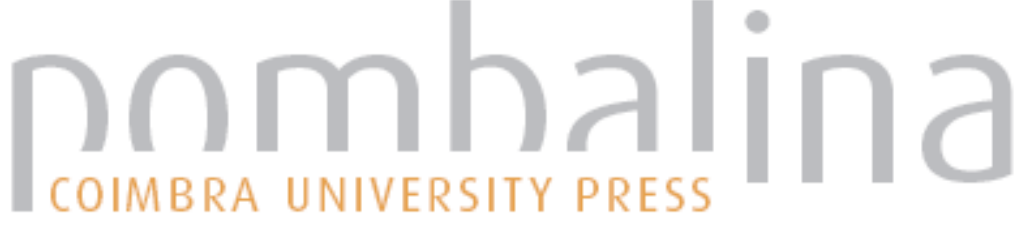

\section{A biotecnologia das plantas e o futuro da agricultura}

\author{
Autor(es): Ho, David
}

Publicado por: Imprensa da Universidade de Coimbra; Gradiva

URL

persistente: URI:http://hdl.handle.net/10316.2/32695

DOI: $\quad$ DOI:http://dx.doi.org/10.14195/978-989-26-0389-6_17

Accessed : $\quad$ 26-Apr-2023 03:02:30

A navegação consulta e descarregamento dos títulos inseridos nas Bibliotecas Digitais UC Digitalis, UC Pombalina e UC Impactum, pressupõem a aceitação plena e sem reservas dos Termos e Condições de Uso destas Bibliotecas Digitais, disponíveis em https://digitalis.uc.pt/pt-pt/termos.

Conforme exposto nos referidos Termos e Condições de Uso, o descarregamento de títulos de acesso restrito requer uma licença válida de autorização devendo o utilizador aceder ao(s) documento(s) a partir de um endereço de IP da instituição detentora da supramencionada licença.

Ao utilizador é apenas permitido o descarregamento para uso pessoal, pelo que o emprego do(s) título(s) descarregado(s) para outro fim, designadamente comercial, carece de autorização do respetivo autor ou editor da obra.

Na medida em que todas as obras da UC Digitalis se encontram protegidas pelo Código do Direito de Autor e Direitos Conexos e demais legislação aplicável, toda a cópia, parcial ou total, deste documento, nos casos em que é legalmente admitida, deverá conter ou fazer-se acompanhar por este aviso.

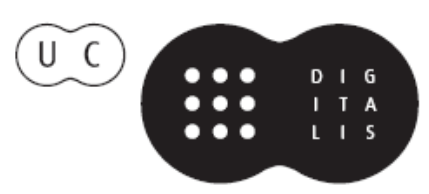


C I E N C I A I B E R T A

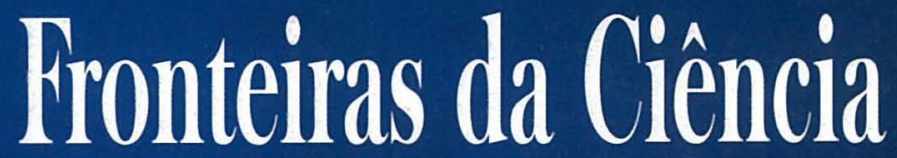

Desenvolvimentos Recentes - Desafios Futuros

RUI FAUSTO • CARLOS FIOLHAIS • JOÃO FILPE QUURRÓ

Coordenadores

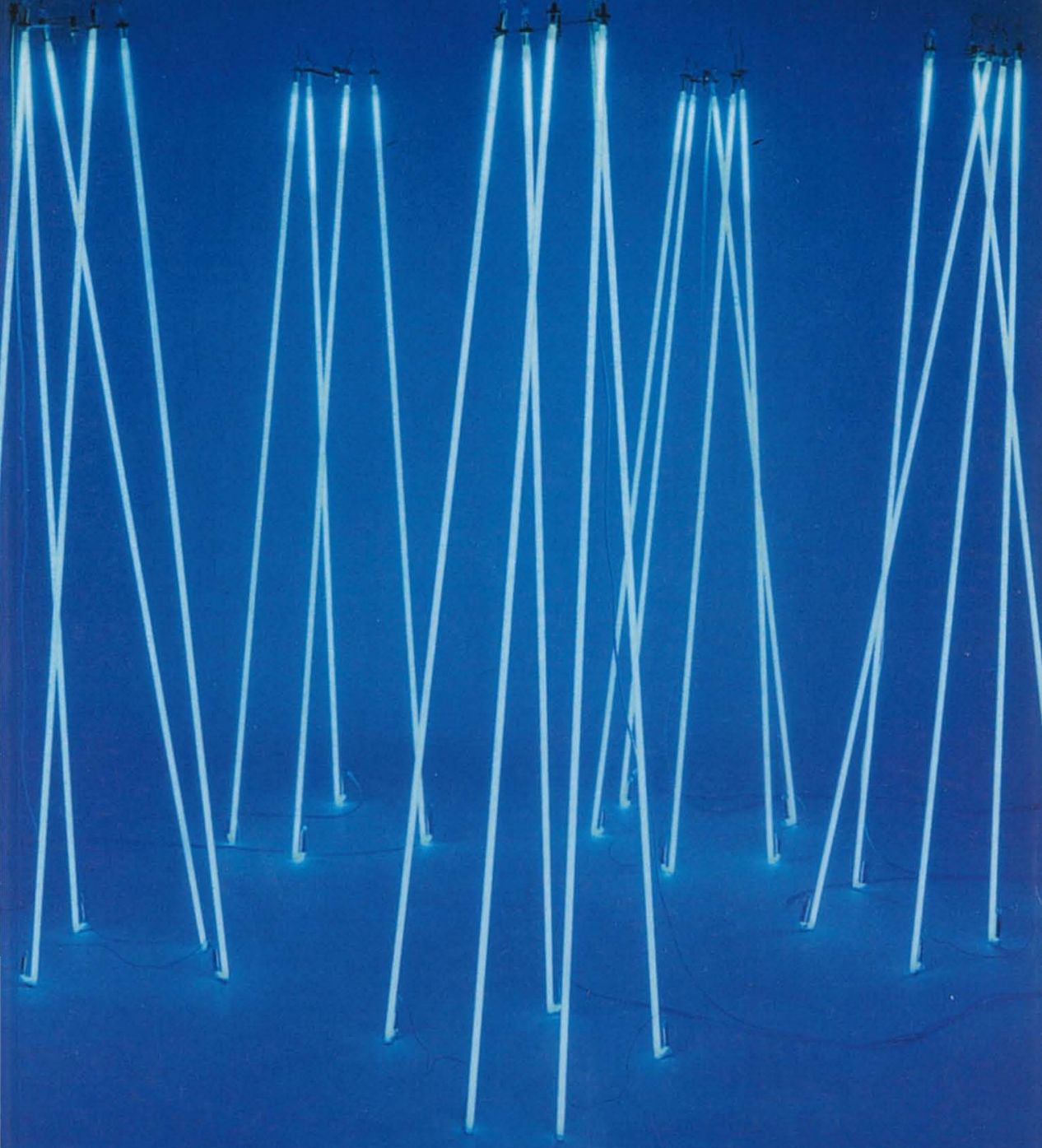

gradiva - Imprensa da Universidade de Coimbra 
(Página deixada propositadamente em branco) 


\section{RUI FAUSTO, CARLOS FIOLHAIS JOÃO FILIPE QUEIRÓ \\ Coordenadores}
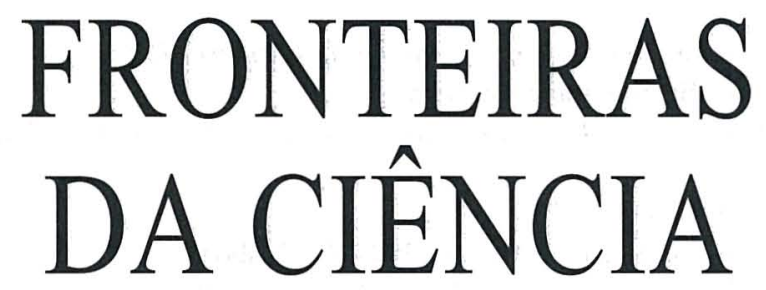

Desenvolvimentos Recentes Desafios Futuros 
(C) Gradiva - Publicações, L. da / Imprensa da Universidade de Coimbra, 2003 Coordenação editorial: Rui Fausto, Carlos Fiolhais e João Filipe Queiró Tradução: Jean Burrows, Vivien Burrows, Rui Fausto, Carlos Fiolhais e João Filipe Queiró

Revisão do texto: Isabel Pedrome

Capa: António Barros [Imprensa da Universidade. Coimbra], sobre imagem de «Águas Vivas», escultura de Silvestre Pestana, 2001

Foto: António Alves; Infografia: ESTÍMULUS [design]; Cortesia: Galeria Alvarez-Arte Contemporânea

Paginação: António Resende e Paula Isabel Jorge

Impressão e acabamento: G.C. - Gráfica de Coimbra, L. ${ }^{d a}$

Reservados os direitos para Portugal por:

Gradiva - Publicações, L. ${ }^{\text {da }}$ e Imprensa da Universidade de Coimbra

Gradiva - Publicações, L.da

Rua Almeida e Sousa, 21, r/c, esq.•1399-041 Lisboa

Telefs. $213974067 / 8 \cdot 213971357 \cdot 213953470$

Fax $213953471 \cdot$ Email: gradiva@ip.pt

URL: http://www.gradiva.pt

Imprensa da Universidade de Coimbra

Rua Antero de Quental, 195 • 3000-033 Coimbra

Telefs. 351239853110

Fax 3512398531 19・e-mail: fjrpress@ci.uc.pt

URL: http://www.imp.uc.pt

ISBN: 972-662-923-3

1." edição: Agosto de 2003

Depósito legal n. ${ }^{\circ} 199$ 463/2003 
David Ho

Universidade de Washington

St. Louis

E.U.A.

\section{A biotecnologia das plantas e o futuro da agricultura}

Eu nasci na Formosa, uma ilha descoberta por navegadores portugueses. Foram eles que lhe deram o nome de Formosa, mas acharam-na uma ilha pouco interessante: estava deserta (isto foi antes da emigração em massa de chineses para Taiwan...). Assim, avançaram para o Japão, para fazerem comércio com os Japoneses. Graças à saída dos Portugueses, tive de aprender chinês em vez de português na escola...

Uma das mensagens mais importantes que quero transmitir é que a agricultura tem sido uma prática biotecnológica desde há mais de 2000 anos. É importante salientar este facto porque a palavra biotecnologia tem sido alvo de grande controvérsia. $\mathrm{Na}$ verdade, se temos agricultura é porque há biotecnologia.

A sociedade humana evoluiu a partir de colectores e caçadores para uma sociedade agrícola. $\mathrm{O}$ homem pré-histórico interrogou-se: Não poderei cultivar alimentos no meu quintal de modo a não ter de ir arriscar a vida quando procuro alimentos na floresta? E isto é biotecnologia!

A primeira coisa que o homem teve de aprender foi a maneira de fazer germinar sementes, o que não é uma tarefa fácil. A maior parte das sementes de plantas selvagens não germina quando queremos. Em geral, no ciclo biológico natural, as sementes passam por períodos de dormência. Assim, ao longo dos anos, os agricultores conseguiram livrar-se da dormência nas sementes, de modo que estas germinassem quando fosse 
mais conveniente para o homem. E esta é a prática comum da agricultura moderna. Será a dormência boa para as plantas? Vejamos os cereais, como as plantas de milho híbrido entre Lisboa e Coimbra, que não têm qualquer dormência. No final do Verão, por volta de Setembro ou Outubro, as sementes caem. Algumas das sementes não recolhidas germinam em apenas alguns dias. Quando o Inverno vem, todas as jovens plantas morrem. Se pensarmos numa perspectiva ecológica, estaremos a mudar o ambiente? Sim, claro que estamos! Mas temos de reflectir sobre se a tecnologia traz ou não mais benefícios do que prejuízos.

A agricultura como uma forma de biotecnologia para um desenvolvimento sustentado iniciou-se há muito tempo. Se eu fosse agricultor há mais de 2000 anos, e se plantasse 100 sementes no meu quintal, quereria decerto recuperar mais do que esse número. Não vale a pena cultivarmos plantas se não obtivermos mais do que o investimento inicial. Assim, com 100 sementes, começaria por obter cerca de 98 plantas e depois milhares de sementes. Comeria muitas delas, mas deveria guardar pelo menos 100, de modo a assegurar a geração seguinte e a poder continuar a agricultura, geração após geração. Certamente que precisaria de água em grande quantidade e de outras coisas, mas não teria de me preocupar com a água fora do meu quintal - onde nem sempre está disponível. Um problema com o desenvolvimento da biotecnologia na agricultura nos últimos séculos é que começámos a introduzir novos materiais nas nossas práticas agrícolas. Introduzimos produtos químicos, por exemplo sob a forma de herbicidas, e estamos a retirar muita água do solo, de tal modo que o subsolo fica por vezes demasiado seco.

A nova biotecnologia, um novo capítulo no livro da agricultura sobre o qual vos quero falar, baseia-se na biologia molecular, nomeadamente na genética molecular. Assim, vou falar do ADN recombinante e da engenharia genética. Procurarei definir estes dois termos. Depois vou passar a descrever casos reais, casos bem sucedidos de biotecnologia moderna.

Um dos casos mais bem sucedidos da biotecnologia antes do desenvolvimento do $\mathrm{ADN}$ recombinante e da engenharia genética pode ser ilustrado por um campo de milho. Num campo de milho é fácil, pela altura, distinguir os chamados milhos inato e híbrido. E a biologia por detrás disto é muito simples: os milhos inatos foram-se sucedendo ao longo de muitas gerações e a respectiva colheita não é muito abundante. Contudo, são muito importantes para produzir milho híbrido. O milho híbrido é, basicamente, o resultado do cruzamento entre duas linhas inatas. O milho híbrido é muito mais alto e o cereal produzido por ele pesa mais do dobro do milho normal. Ora, isto nada tem a ver com o ADN recombinante nem com a moderna 
engenharia genética. Trata-se de uma versão «suave» da genética. Contudo, se chamarmos engenharia genética à manipulação de recursos genéticos, isto é decerto engenharia genética. Assim, não devemos ficar alarmados com a expressão "engenharia genética» porque temos vindo a usá-la ao longo dos tempos. Posso assegurar-vos que o milho nos campos entre Lisboa e Coimbra é milho híbrido. É um produto da engenharia genética, quer se goste quer não!

Vou referir-me agora aos princípios básicos da tecnologia do ADN recombinante e da engenharia de plantas. Depois de explicada a terminologia e a abordagem básica poderei ilustrar quatro pontos que considero muito importantes.

O primeiro ponto é que a biotecnologia acelera as mudanças genéticas e aumenta a diversidade. A biotecnologia não cria novas alterações, apenas acelera as alterações que a natureza tem vindo a fazer ao longo do tempo. Com a tecnologia moderna podemos fazê-las mais rapidamente. Uma vez que passa a haver mais mudanças, estamos, na realidade, a aumentar a diversidade. Em contraste com a crença comum de que a biotecnologia diminui a diversidade, o facto é que ela a aumenta.

O segundo ponto é que a biotecnologia permite uma melhor administração dos recursos biológicos. Mesmo antes da engenharia genética, havia muitos recursos biológicos, sob a forma de plantas e animais diferentes, etc. Alguns desses recursos não estavam muito bem documentados. Por outras palavras, quando alguém vê uma planta com uma flor verde e uma outra com uma flor vermelha apenas descreve a diferença entre as duas pela diferença entre a cor das respectivas flores o que não tem grande precisão. Com a biotecnologia somos capazes de definir porque tem a segunda planta uma flor vermelha. Há uma diferença genética: podemos descrever a diferença entre as duas plantas do ponto de vista químico.

O terceiro ponto é que a biotecnologia pode ser amiga do ambiente. Os meus termos são cuidadosos: pode ser. Se procedermos sempre de forma correcta, a biotecnologia pode ser protectora do ambiente. De novo, esta afirmação parece contrariar a nossa intuição. A maioria das pessoas pensa que a biotecnologia não é amiga do ambiente, mas eu espero apresentar argumentos, mostrando que os casos modernos de biotecnologia vegetal são, de facto, protectores do ambiente.

$\mathrm{O}$ último ponto pode não ser muito familiar. O conceito original de agricultura consiste em utilizar plantas ou animais para produzir alimentos e fibras. Mas agora, graças à biotecnologia moderna, as plantas e os animais não servem apenas para produzir alimentos e fibras; podemos usá-los para fazer muito mais coisas. 
Apresentemos a biologia molecular básica. O ADN pode ser definido quimicamente com muito rigor, embora não faça sentido especificar todos os seus átomos constituintes. Apesar de parecer estruturalmente muito complexo, na realidade o ADN é uma molécula muito simples; basicamente contém fosfatos e açúcares, que se organizam de uma maneira repetida. Todos os ADNs, sejam eles de humanos, de plantas ou de bactérias, contêm exactamente os mesmos açúcares e fosfatos. Mas ligadas aos açúcares existem as chamadas bases. Estas são mais complicadas do que os açúcares, mas não demasiado: as suas estruturas estão muito bem estudadas. Assim, no ADN, na maior parte das vezes, existem quatro bases diferentes, por exemplo citosina, guanina, adenina e timina (CGAT). As bases são estruturas bem definidas quimicamente, localizadas em diferentes posições da cadeia de ADN (figura 1).

Assim, a linguagem do ADN é basicamente uma linguagem de quatro letras, ao contrário da das línguas europeias, que têm cerca de 26 . Uma língua de quatro letras é muito mais monótona do que uma linguagem de 26. Contudo, uma linguagem de quatro letras é muito mais interessante do que o código binário da linguagem de computador. Já que um computador, que apenas lida com zeros e uns, pode fazer muitas coisas, então também se podem fazer muitas coisas com uma linguagem de quatro letras. Esta é, essencialmente, a razão por que quase todos os fenómenos biológicos, incluindo em parte os traços de comportamento, podem ser relacionados com o ADN, sendo determinados pela sequência das bases que constituem a sua cadeia. Como a linguagem biológica só tem quatro letras, as cadeias de ADN têm de ser muito longas para poderem conter toda a informação necessária à vida, oferecendo suficientes possibilidades de combinação das suas unidades constituintes (sequências).

Habitualmente, o conteúdo de ADN num dado organismo é enorme; uma simples bactéria possui vários milhões de bases. No caso de um ser humano, estamos a falar de algumas centenas de milhões de bases ou mesmo mais. E a moderna tecnologia tem-nos permitido determinar a sequência completa das bases, de um extremo ao outro de uma molécula do ADN. Se esta molécula for suficientemente curta - tal como acontece com o ADN de uma bactéria, esta tarefa é bastante simplificada. Foram já sequenciados alguns genomas de bactérias, sendo o termo genoma a designação do conjunto de todos os genes (sequências de bases que desempenham funções específicas; o gene constitui a unidade básica da hereditariedade). Assistimos hoje a um grande esforço mundial para decifrar o genoma humano - esta é uma tarefa muito mais difícil, apesar de as dificuldades não serem intransponíveis. A projecção é que, dentro de 15 a 20 anos, teremos decifrado toda a sequência do genoma humano. 
Lembremos que o organismo humano é muito mais complicado do que todos os outros organismos. Antes de o genoma humano ter sido decifrado, teremos decerto decifrado o genoma de várias plantas e animais.
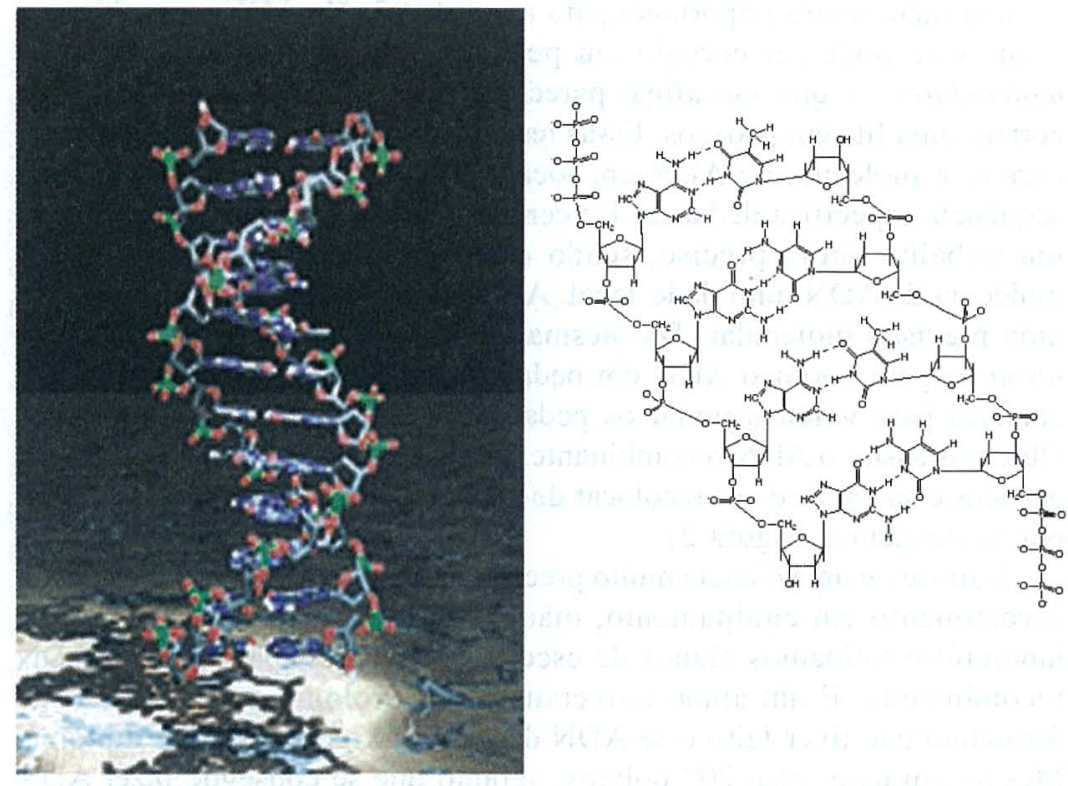

Fig. $1-a$ ) Representação esquemática tridimensional de uma porção da molécula de $A D N$ b) Estrutura química de um segmento de $A D N$, mostrando os seus constituintes fundamentais (açúcares, fosfatos e bases)

A informação que permite traduzir a sequência de aminoácidos numa proteína reside no ADN. Uma vez que as proteínas, entre as quais as enzimas, são catalisadores biológicos, precisamos delas para fazer todas as coisas que uma célula tem de fazer. O ADN não pode fazer essas coisas directamente, uma vez que é apenas o projecto de informação. Assim, deve existir um processo de traduzir a informação, deve haver uma maneira de ler o código inscrito numa molécula de ADN. A maneira como o sistema biológico lê o código consiste em tomar três bases de cada vez. Assim, cada codão genético contém três bases. Cada posição tem quatro possibilidades (CGTA), o que conduz a 64 permutações diferentes. Como a linguagem das proteínas inclui 20 aminoácidos diferentes, com 64 permutações diferentes temos o 
suficiente para codificar a informação necessária à construção das proteínas. Uma vez a informação transferida do ADN para as proteínas, estas podem executar as suas tarefas específicas, consoante as sequências de aminoácidos que as constituem.

Um facto muito importante para a construção do ADN recombinante é que este pode ser cortado em pedaços com as chamadas tesouras moleculares - que são afinal parecidas com as tesouras normais, que cortam uma fita em pedaços. Essas tesouras moleculares são enzimas que cortam a molécula de ADN em locais específicos, definidos por uma sequência específica de bases. Há centenas dessas enzimas, que realizam um trabalho muito preciso, sendo cada uma delas capaz de cortar a molécula de ADN num dado local. As enzimas realizam esta tarefa com uma precisão molecular. Da mesma forma que podemos usar aquelas tesouras para cortar o ADN em pedaços, podemos também usar outras enzimas para voltar a juntar os pedaços de um modo bastante preciso. Obtemos assim o ADN recombinante. Basicamente, cortamos o ADN em pedaços e só temos de os recolocar de uma certa maneira, conforme aquilo que pretendemos (figura 2).

Trata-se de uma ciência muito precisa, mas exequível com um modesto investimento em equipamento, mão-de-obra e consumíveis. No meu laboratório treinamos alunos de escolas secundárias para fazer o ADN recombinante. E um aluno universitário de Biologia que antes da sua formatura não tiver feito esse $\mathrm{ADN}$ decerto não receberá o seu diploma. Mesmo em casa, com 200 dólares, garanto que se consegue fazer ADN recombinante. O ADN é uma molécula pura e as enzimas são quimicamente definidas, de modo que se pode efectuar toda a operação num tubo de ensaio. Mas o ADN num tubo de ensaio não é muito interessante, pelo que se inventaram maneiras de o introduzir em plantas, animais ou micro organismos. Existem muitas técnicas para o fazer. Algumas são biológicas, como os vírus (habitualmente usamos vírus desarmados, isto é, vírus que não causam quaisquer problemas), mas podemos também introduzir ADN na célula usando transportadores físicos, por exemplo sujeitando-a a um campo eléctrico que abre os poros da membrana do plasma (a membrana mais externa da célula) até que o ADN possa entrar na célula. Ou podemos mesmo disparar o $\mathrm{ADN}$ como uma bala dirigida à célula.

No meu laboratório usamos também nanotubos, que são estruturas de carbono, como porta-aviões que transportam o ADN para a célula. Estas estruturas são muito fortes e estáveis. O ADN, por outro lado, é muito frágil, partindo-se facilmente por uma acção física. Contudo, se introduzirmos o $\mathrm{ADN}$ num nanotubo, a molécula pode entrar na célula sem se partir. Todas estas técnicas são hoje padronizadas. 

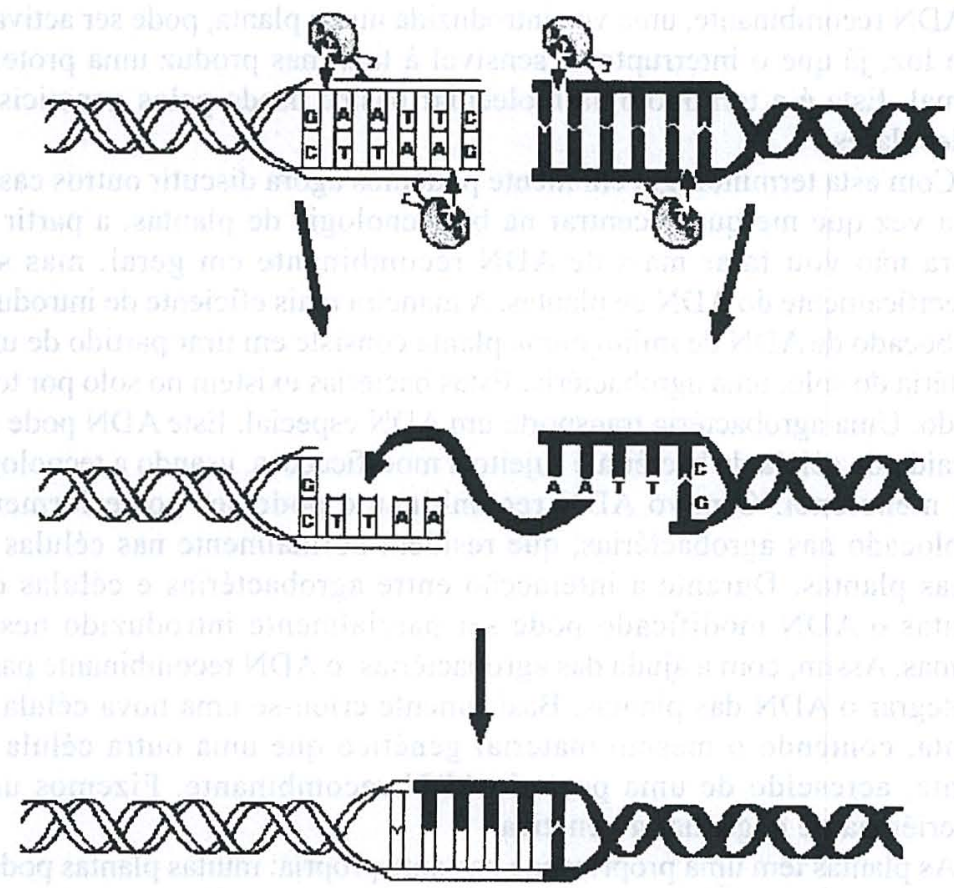

Fig. 2 - Formação do ADN recombinante. Após corte das moléculas de ADN da célula alvo e exógeno por acção de enzimas apropriadas, o segmento de $A D N$ exógeno é incorporado no ADN celular por acção de outras enzimas.

$O$ resultado é uma molécula de $A D N$ editada ou ADN recombinante.

Num gene focamos a nossa atenção numa sequência do código que corresponde a uma parte activa do ADN. Esta sequência de código pode provir de plantas, animais ou outros organismos, mas pode ser ligada a um outro pedaço de ADN a que chamamos promotor e que pode também ter diferentes proveniências. O que é o promotor? É um interruptor molecular, um interruptor que funciona de forma análoga ao interruptor da luz em nossas casas. Precisamos de um interruptor molecular para regular a actividade da sequência de código. Os promotores são geralmente específicos das espécies biológicas. Por outras palavras, se dispomos de um promotor proveniente de plantas sensíveis à luz, depois de ligado a uma 
sequência proveniente de um animal, este novo gene, esta nova molécula de $\mathrm{ADN}$ recombinante, uma vez introduzida numa planta, pode ser activada com luz, já que o interruptor é sensível à luz, mas produz uma proteína animal. Esta é a terminologia molecular básica usada pelos geneticistas moleculares.

Com esta terminologia em mente podemos agora discutir outros casos. Uma vez que me quero centrar na biotecnologia de plantas, a partir de agora não vou falar mais de ADN recombinante em geral, mas sim especificamente do ADN de plantas. A maneira mais eficiente de introduzir um bocado de ADN de milho numa planta consiste em tirar partido de uma bactéria do solo, uma agrobactéria. Estas bactérias existem no solo por todo o lado. Uma agrobactéria transporta um ADN especial. Este ADN pode ser extraído da célula da bactéria e sujeito a modificações, usando a tecnologia que mencionei. O novo ADN recombinante pode ser posteriormente recolocado nas agrobactérias, que residem normalmente nas células de certas plantas. Durante a interacção entre agrobactérias e células das plantas o ADN modificado pode ser parcialmente introduzido nestas últimas. Assim, com a ajuda das agrobactérias, o $\mathrm{ADN}$ recombinante passa a integrar o ADN das plantas. Basicamente criou-se uma nova célula de planta, contendo o mesmo material genético que uma outra célula de planta, acrescido de uma peça de ADN recombinante. Fizemos uma experiência de engenharia genética!

As plantas têm uma propriedade bastante própria: muitas plantas podem ser cultivadas a partir de células singulares ou quase. Depois, num certo momento e sob certas condições, com a ajuda de certas hormonas vegetais, podemos regenerar uma planta completa a partir de uma só célula. A importância desta descoberta (que tem cerca de 30 ou 40 anos) é que, se tivermos criado uma supercélula de uma planta, isto é, uma célula vegetal concebida por engenharia genética, podemos obter uma planta completa exactamente com o mesmo arranjo genético. Obtemos assim uma planta transgénica. Acontece que, se tivermos uma planta completa, temos uma população inteira e, se tivermos uma população inteira, podemos apanhar as sementes e vendê-las. Esta é a promessa da biotecnologia vegetal.

Poderão dizer: Grande coisa, isso é a clonagem! Desde há pouco que os cientistas clonam ovelhas ou vacas... Muito bem. Mas essa clonagem foi feita apenas recentemente, ao passo que os biólogos das plantas foram capazes de fazer a mesma coisa, em tubos de ensaio, vai para 40 anos e, no mundo real, desde que existe agricultura. Todas as plantas de milho que se vêem nos campos entre Lisboa e Coimbra, têm exactamente o mesmo arranjo genético. Assim, a clonagem é uma rotina, uma prática muito comum em biologia vegetal. 
Vamos agora a casos reais. A primeira coisa que pretendo transmitir é que a biotecnologia acelera alterações genéticas e aumenta a diversidade. Vou usar um exemplo que tem a ver com o controlo do amadurecimento de tomates. Porque queremos controlar esse processo? Os tomates são bastante comuns na alimentação de muitos povos, graças a Marco Pólo e a Cristóvão Colombo. No entanto, no comércio moderno, os tomates são normalmente recolhidos quando ainda estão verdes, uma vez que têm de ser enviados da quinta para a cidade, o que habitualmente demora algum tempo. Se forem colhidos demasiado tarde, os tomates estão demasiado maduros na altura de serem vendidos. O processo de amadurecimento da fruta, incluindo dos tomates, é controlado por uma hormona vegetal chamada etileno. O etileno é uma molécula muito simples, constituinte de um gás. É uma hormona que ocorre na natureza e é produzida a partir de um aminoácido muito mais complicado, a metionina. No processo de transformação participam muitas enzimas complexas e há um intermediário muito importante que é uma molécula de forma triangular chamada ACC (o nome completo é muito comprido, pelo que se usa o nome abreviado).

Quase todas as células, incluindo as de bactérias, animais e plantas, contêm metionina, mas só as plantas conseguem produzir etileno, porque só estas querem ter fruta madura. As plantas conseguem produzi-lo porque têm duas enzimas exclusivas que catalizam a formação de ACC e a conversão deste em etileno (a sintase e a oxidase do ACC, respectivamente). A fim de controlar o amadurecimento da fruta, precisamos então de controlar a produção de etileno. Nos últimos anos, os biólogos moleculares de plantas conseguiram isolar os genes que codificam a sintase e a oxidase do ACC. Uma vez que temos os genes isolados, tudo se torna rotina pois ficamos a conhecer a forma de codificar a sequência de aminoácidos que formam as enzimas.

Os cientistas foram capazes de reintroduzir estes genes em plantas de tomate. A orientação do gene foi invertida, mas o promotor continuou localizado no mesmo sítio. Começou-se por produzir uma fita positiva do gene-pai; este gene invertido produz uma fita negativa dos genes progenitores, cancelando-se as fitas negativa e positiva. $\mathrm{O}$ cancelamento mútuo significa que numa célula não se vai produzir sintase funcional do $\mathrm{ACC}$ ou que não se vai produzir oxidase funcional do ACC. Faltando estes catalisadores biológicos, não pode ocorrer a reacção bioquímica. Assim, não há $\mathrm{ACC}$, não se produz etileno e a fruta não consegue amadurecer.

O tomate normal ficará vermelho, amadurecerá, eventualmente de mais. Contudo, um tomate feito com engenharia genética, com o gene invertido codificando a sintase do $\mathrm{ACC}$ ou a oxidase do $\mathrm{ACC}$, não amadurecerá; permanecerá verde, de modo que se pode conservar mais 
tempo na planta-mãe. Uma vantagem óbvia é que, quanto mais tempo as frutas permanecerem na planta-mãe, melhor será o seu sabor.

As versões comerciais desta planta resultante da engenharia genética são chamadas flavour-saver; de facto, o tomate assim produzido sabe muito melhor. No entanto, conseguirá alguém vender o tomate transgénico de cor verde? Possivelmente não; apesar do seu melhor sabor, ninguém vai comprar o tomate verde. Assim, o que temos de fazer? Na noite antes de colocarmos o tomate nas prateleiras dos supermercados, damos-lhe gás. $\mathrm{O}$ etileno é um gás industrial muito simples. Consegue-se, por poucos dólares, comprar uma botija de etileno, gasear o tomate e, no dia seguinte, obter um lindo tomate vermelho, igual ao que se tinha, excepto que é vermelho em vez de verde; esteve na planta-mãe mais tempo que os tomates não geneticamente modificados e por isso o seu sabor é mais intenso.

Idealmente, isto devia ser um bom negócio: trata-se de combinar informação biológica e tecnologia com um objectivo útil. Mas este produto particular, o flavour-saver, não se tem vendido muito bem. Uma das razões para tal é que a empresa que o produz é demasiado gananciosa e fixou um preço muito elevado para a comercialização do produto. Ora os consumidores preferem, naturalmente, comprar o tomate mais barato, sem sabor, a pagar dez vezes mais pelo supertomate com sabor. Assim, estamos perante um sucesso científico que é um insucesso comercial. Numa certa perspectiva trata-se de um caso falhado...

A lição que aprendemos com o flavour-saver é que hoje podemos alterar as plantas. Não era lá muito provável que um gene evoluísse do modo em causa. Embora tal evolução pudesse acabar por ocorrer na natureza, levaria muito, muito tempo. Mas os engenheiros genéticos levam um ano, no máximo, a concretizar alterações deste tipo. É por isso que digo que a engenharia genética permite acelerar as alterações e a diversidade biológica.

O segundo caso, um pouco mais bem sucedido porque os empresários não são tão somíticos, está relacionado com o amido contido nas batatas. $\mathrm{O}$ amido é um dos principais ingredientes da batata e gostamos de ter batatas com muito amido. $\mathrm{O}$ amido é habitualmente sintetizado numa organela especial da célula por um processo muito complicado. A química respectiva está bem compreendida e a sua descrição não cabe aqui. Pretendo apenas realçar três passos distintos, três reacções quimicamente bem definidas, catalizadas por três enzimas diferentes.

Como vimos, todas as enzimas, todas as proteínas, têm um gene que as codifica. A sintase do amido, uma enzima importante na formação de amido, é habitualmente sujeita a inibição de feedback. Isto é, se se 
produzir uma certa quantidade de amido, depois de o amido se acumular, o sistema de produção da enzima desliga-se sozinho. A inibição por feedback é muito comum. Assim, seria interessante obter um mutante da sintase do amido que não estivesse sujeito a inibição por feedback. Nesse caso poder-se-ia continuar a produzir amido, pelo que o conteúdo de amido na batata seria maior. Como fazer isto?

Acontece que a sintase de amido em plantas, em particular nas batatas, é muito parecida com a sintase do amido de uma bactéria. Assim, procuraram-se mutantes genéticos em bactérias que transportassem um gene de sintase de amido não sujeito a inibição por feedback. Investigadores da Universidade Estadual do Michigan conseguiram isolar estes mutantes. Uma vez isolados os mutantes, isolaram o gene da bactéria e usaram depois tecnologia genética para ligar as bactérias mutantes a um promotor vegetal. Obtiveram assim uma molécula de ADN recombinante. Introduziram essa molécula de ADN na batata e esta produziu mais amido, já que possuía a nova sintase de amido, não sujeita a inibição de feedback.

Tenho aqui duas batatas: uma é do tipo natural, não manipulada. Marcou-se com iodo para determinar a quantidade de amido que contém. A interacção do iodo com o amido origina uma cor azul cuja intensidade é proporcional à quantidade de amido. Esta outra batata é resultado de manipulação genética pela empresa Monsanto: a cor azul é mais forte. $\mathrm{Eu}$ não quero promover a empresa, trata-se apenas de ciência. $\mathrm{Na}$ realidade, este assunto foi publicado sob a forma de artigo numa reputada revista científica. (De facto, não sei porque é que a empresa se chama Monsanto. Os cientistas da Monsanto também não sabem, mas quando estive em Lisboa percebi que Monsanto é um nome português.) É muito fácil, portanto, aumentar o conteúdo de amido da batata. Um maior conteúdo de amido é obviamente benéfico. $\mathrm{O}$ amido, mais denso do que a água, substitui a água. E, como as batatas se vendem ao peso, faz-se naturalmente mais dinheiro com batatas mais pesadas. Uma vantagem para a saúde é que, quando se fritam batatas em óleo, o óleo substitui, em geral, a água. Quanto menos água tiver a batata, menos óleo reterá, de modo que as batatas fritas ficam mais saudáveis.

De novo, devido ao ADN recombinante, podemos acelerar as alterações e aumentar a diversidade. Normalmente, a possibilidade de haver um gene bacterial (especialmente um gene de bactéria mutante) em plantas não é muito elevada. Embora possa ocorrer, demoraria muito tempo a concretizar. Todavia, devido ao ADN recombinante, conseguimos o gene num ano ou dois. Na realidade, ficamos com uma população de plantas muito mais diversa do que a que se teria por uma via natural. 
Vamos agora ao segundo ponto: a biotecnologia permite uma melhor gestão de recursos biológicos. Tal acontece porque todos os recursos e todos os fenómenos biológicos podem ser relacionados com o ADN e porque a informação importante no ADN é a sequência das suas bases. Assim, se tivermos um modo de documentar a diversidade de sequências de bases, temos um meio muito mais preciso de documentar os recursos biológicos. Porque é isso importante? Muitos geneticistas têm tentado fazer o mapeamento genético da maioria dos cereais de grande colheita (trigo, cevada, arroz); em particular, pretendem determinar qual é o cromossoma onde se localiza um dado gene porque, de outra forma, não o poderiam manipular facilmente. No entanto, são precisos anos, ou mesmo décadas, para que os geneticistas tradicionais consigam o que pretendem. Por exemplo: o milho é provavelmente o sistema mais bem estudado do ponto de vista genético. Os geneticistas de milho, centenas ou milhares deles, têm vindo a fazer este trabalho desde os anos 20, mas o mapa genético dos cromossomas do milho, apesar de ter hoje um aspecto impressionante, permanece ainda incompleto. No entanto, hoje em dia, já não fazemos apenas genética tradicional. Sabemos que o ADN tem sequências exclusivas e que estas podem ser identificadas pelos locais de corte das tesouras moleculares.

Assim, consideremos dois hipotéticos $\mathrm{ADN}$, um de um pai e outro doutro. Estes são basicamente a mesma planta, mas o seu ADN é ligeiramente diferente, porque cada indivíduo é um pouco diferente. Adicionamos aos dois $\mathrm{ADN}$ locais de corte: o primeiro pai terá um local de corte adicional, ao passo que o segundo pai terá um outro local de corte. Então, se cortarmos os $\mathrm{ADN}$, o primeiro pai gerará um $\mathrm{ADN}$ longo e um ADN curto. Podemos separar os dois pedaços de ADN por electroforese de gel. O segundo pai, por seu lado, como é cortado noutro sítio, ficará com dois cordões de tamanho médio. Se tivermos um rebento que se suspeita provir do cruzamento entre os dois pais, ele deve possuir os quatro cordões. Isto é parte da versão mais simples do mapeamento de um gene usando o nosso conhecimento químico do material genético. Foram desenvolvidas técnicas mais sofisticadas, pelo que podemos fazer coisas muito melhores. Mas a mensagem a extrair é que, com este tipo de abordagem não temos de efectuar um cruzamento real (cruzamento genético). Conseguimos compreender o mapa físico de muitos genes e caracterizar fisicamente os recursos biológicos de um modo muito preciso.

Para um cereal como o arroz ou o trigo, temos a vantagem da experiência acumulada de muitos geneticistas e de muitos agricultores. Assim, mesmo sem a nossa moderna tecnologia, dispomos de alguma informação. Mas tal já não é o caso de outras colheitas, que não são tão comuns. Dou o 
exemplo da papaia. A papaia é muito importante no Sudeste Asiático; mas poder-se-á aliciar um cientista europeu ou norte-americano para fazer o mapa genético da papaia do Sudeste Asiático? Possivelmente nenhum o fará, a menos que haja uma fundação que queira financiar o projecto. Por isso ninguém conhece o mapa genético da papaia. O Sudeste Asiático, para trabalhar nesta ou noutra colheita importante para si, tem de confiar em si próprio e na moderna tecnologia. Em poucos anos os cientistas locais poderão recuperar o atraso. A tecnologia ajuda-nos, de facto, a gerir melhor os recursos biológicos.

O terceiro ponto é que a biotecnologia pode ser amiga do ambiente. Apresentarei alguns casos. O primeiro consiste em substituir um herbicida mau e ineficiente por um outro bom e eficiente. O ideal seria não usar nenhuns produtos químicos. Mas quantos países poderiam sobreviver sem utilizar produtos químicos nos seus campos? Neste momento eu diria: nenhum. Damo-nos ao luxo de ter agricultura biológica em certos locais, mas ela representa uma parte muito pequena da produção agrícola global. Uma vez que temos de usar herbicidas - produtos químicos que eliminam todas as ervas -, porque não utilizar herbicidas bons e eficientes em vez de herbicidas maus e ineficientes? O meu exemplo é um herbicida da Monsanto chamado Ready Roundup. Este é o nome comercial, já que o nome químico é glifosate. A glifosate é um composto muito simples, contendo fosfato e uma cadeia de carbono simples. A sua eficácia foi provada: é um herbicida muito geral que não provoca problemas de saúde. A má notícia é que tem uma acção demasiado geral: mata tudo o que é vegetal, incluindo a planta da colheita que se pretende proteger!

Então onde é que normalmente se usava a glifosate? Por exemplo nos carris ferroviários e nas bermas das auto-estradas, de modo a impedir que as plantas crescessem nesses locais. Mas agora podemos usá-la de um modo muito mais útil, desenvolvendo plantas transgénicas nas quais se introduziu um gene resistente à glifosate. Estas plantas, ao contrário das ervas daninhas, resistirão à glifosate. Se os campos forem pulverizados com glifosate, todas as ervas morrem, mas as plantas com o gene resistente sobrevivem.

Como é que isso se faz? Como os restantes seres vivos, as plantas necessitam de produzir os aminoácidos necessários ao seu desenvolvimento. Na produção de alguns desses aminoácidos participa uma enzima cujo nome abreviado é sintase do EPSP, que se encontra codificada geneticamente no ADN das plantas. A glifosate inibe o funcionamento da sintase do EPSP, o que conduz à morte da planta. Um aspecto importante é que o gene que codifica a sintase do EPSP não pode ser passado aos animais, o que faz que a glifosate não possa ser utilizada para inibir 
qualquer função biológica nos animais. É por esta razão que a glifosate é um herbicida: apenas mata plantas e é por isso que não provoca quaisquer problemas de saúde. Visto que todas as plantas necessitam da sintase do EPSP, a estratégia passou por procurar um mutante desta enzima que não fosse inibido pela glifosate. Assim, seguindo a mesma estratégia, os cientistas da Monsanto e de outra empresa, em colaboração com cientistas universitários, conseguiram isolar um gene mutante da enzima sintase do EPSP que não podia ser inibida pela glifosate. Uma vez identificado o gene, tudo é muito fácil: fabrica-se o $\mathrm{ADN}$ recombinante $\mathrm{e}$ introduz-se o gene nas plantas, por exemplo nas plantas de feijão, de soja ou de milho.

Tenho aqui plantas de feijão de soja com um gene resistente. Para fazer qualquer comparação precisamos de um conjunto de controlo, isto é, de plantas de feijão não manipuladas. Pulverizámos glifosate em doses diferentes. As plantas transgénicas sobrevivem muito bem, mesmo a uma concentração muito alta de glifosate. As plantas normais são mortas a partir de uma dada concentração de glifosate, tal como as ervas, porque não têm o gene resistente. Os cultivadores de feijão de soja podem, portanto, actualmente, usar glifosate, que é muito eficaz e não comporta riscos significativos para a saúde.

Como é que as pessoas cultivavam feijões de soja antes da engenharia genética? Usavam um outro herbicida, chamado Lasso. Mas o Lasso é mau. Provou-se que era ineficaz e que causava doenças. No entanto, ainda hoje se usa. De facto, ainda hoje, se se tiver qualquer produto baseado em feijão de soja, provavelmente usou-se Lasso nas sementes do feijão. Agora a escolha é do consumidor: ou opta pelos produtos com Lasso ou pelo feijão de soja com roundup ready ou equivalente. A escolha deveria ser óbvia: o roundup é mais barato, mais eficaz e não perturba a saúde. No entanto, a expressão transgénico ainda encontra algumas reticências junto dos consumidores. Podem dizer: Devia haver uma terceira escolha. E há: a terceira escolha é não usar nenhuns herbicidas. Tal seria o ideal, mas quem não quer usar herbicidas não deve cultivar feijões de soja; os feijões não sobrevivem porque as ervas os atacam. As plantas de soja são pequenas e débeis.

Há uma forma óbvia de fazer agricultura biológica: podemos ir aos campos e arrancar as ervas com as mãos. Se tivermos uma propriedade pequena, tal não constitui nenhum problema; mas, se tivermos alguns hectares, precisaremos de um exército...

Eu não digo que dispomos da resposta final, mas estamos a efectuar grandes progressos usando a biotecnologia. Devemos procurar avançar para níveis cada vez melhores. 
Passo então a um outro caso, que consiste em substituir os insecticidas químicos por controladores biológicos. Estou agora a falar de algo mais difícil. Os insecticidas são produtos químicos para exterminar insectos e os insectos estão mais próximos dos humanos do que as plantas. É fácil obter um produto químico que mate plantas sem fazer nenhum mal aos animais, mas agora queremos matar um animal (um insecto) sem causar nenhum dano aos seres humanos... E os insecticidas têm sido utilizados de forma rotineira nos campos: é difícil encontrar um agricultor que nunca os tenha usado. Os agricultores têm de usar insecticidas e a maioria destes são muito desagradáveis - as pessoas que fazem jardinagem sabem que os insecticidas cheiram terrivelmente mal. Assim, no mínimo, a vida social de um agricultor sofre com o uso de insecticidas, mesmo que ele se mantenha saudável. Foram, com efeito, detectados problemas de saúde relacionados com os insecticidas. Que fazer?

Acontece que há uma outra bactéria do solo, com o nome de Bacillus Thuriegiensis (BT), que produz uma proteína com a forma de um cristal que tem uma acção insecticida: consegue destruir os insectos ligando-se a uma enzima nos intestinos do insecto. Ora esta enzima é muito diferente da sua correspondente em humanos e outros animais. A proteína produzida pela BT não tem efeitos nos humanos nem nos animais, mas sim nos insectos, ou melhor, apenas em certos grupos deles.

Temos assim uma proteína cujo gene pode ser isolado, introduzido em plantas e revelado por um promotor (um interruptor, recorde-se). Estas plantas passarão a produzir, rapidamente, a proteína da bactéria $\mathrm{BT}$ com acção insecticida.

As plantas da batata têm normalmente muitos bichos. Os bichos da batata do Colorado, por exemplo, são devastadores. Sujeita a um ataque deles, a planta morre em algumas horas. Não sei como são os bichos da batata portugueses, mas os do Colorado são terríveis. Agora temos de seguir a estratégia da engenharia genética, expressando a proteína Bacillus Thurigiensis; se tivermos uma proteína BT expressa na batata notamos a diferença: a batata que resulta da engenharia genética é verde, enquanto a batata normal é amarela, o que significa que está morta.

E não temos de nos ficar pelas batatas, podemos examinar o algodão. No sul dos Estados Unidos produz-se bastante algodão. Os Estados Unidos são o maior produtor de algodão do mundo, seguidos pela China. Ora, tanto nos Estados Unidos como na China são utilizadas toneladas de insecticidas em campos de algodão. Aqueles produtos químicos não são normalmente recomendáveis, mas podemos substituí-los expressando o gene BT no algodão. $\mathrm{O}$ algodão BT distingue-se bem do algodão desprotegido porque este último não tem tantas bolas brancas de algodão... 
Agora vejamos algum do trabalho que eu próprio faço. Seria injusto que eu não falasse da minha própria investigação, porque até aqui tenho falado da investigação dos outros. O meu trabalho tem-se centrado no modo como as plantas respondem ao stress ambiental. As pobres plantas não podem mover-se, têm de sobreviver quando a temperatura é demasiado alta ou demasiado baixa e quando não há água suficiente ou há água a mais. Para nós, seres humanos, é fácil: quando a temperatura é alta ligamos o ar condicionado e quando a temperatura é baixa ligamos o aquecimento. Alteramos o nosso ambiente, ao contrário das plantas. As plantas estão permanentemente sujeitas ao stress ambiental. Como é que esse stress afecta a sua produtividade?

As estatísticas de quatro colheitas importantes nos Estados Unidos (milho, trigo, soja e batatas) nos últimos trinta anos indicam que, num ano bom, a colheita é três vezes maior do que a média. Isso significa que apenas um terço do potencial genético de uma cultura é normalmente realizado e que dois terços se perdem devido ao stress ambiental. Em causa, só nos Estados Unidos, estão cerca de 200 milhões de dólares num bom ano (num ano mau é bem pior!).

Vou encurtar uma história longa. Há cerca de dez anos, usávamos uma abordagem muito típica da biologia molecular que chamamos um molho de genes. Parte dos genes são muito susceptíveis ao stress ambiental, de modo que um certo sinal representa o nível de expressão. Recolhemos dados para rebentos, plantas com raízes, plantas desidratadas, plantas tratadas com cloreto de sódio e respectivos controlos. A concentração de cloreto de sódio é 150 mili-molar (equivalente à da água do mar). Diminui-se a temperatura de normal para baixa, voltando depois à normal, e também se varia a temperatura de normal para alta voltando depois à normal. Um certo gene é expresso sempre que a planta estiver sob stress; só há uma cópia desse gene na planta da cevada, o cereal que usamos habitualmente. Isto significa que aquele gene tem de ser capaz de responder a diferentes formas de stress ambientais. Assim, a questão que apresentámos a nós próprios foi a seguinte: se este gene tem um papel importante, porque não o testamos?

Introduzimos o gene noutra planta usando um interruptor bastante activo de modo que o gene pudesse ser expresso num nível muito alto, mesmo sem stress (normalmente o gene seria apenas expresso quando a planta estivesse sob stress, mas queríamos expressar este gene a um nível muito alto sem stress). Estudámos a planta do tabaco porque estas plantas são tecnicamente fáceis de manipular. Comparámos o tabaco transgénico com o tabaco inato (controlo). As plantas são exactamente as mesmas, mas a planta transgénica possui mais um gene - o gene que isolámos 
da cevada e que obrigámos a expressar-se num nível mais alto, mesmo sem stress, de modo que este fosse sempre expresso. Agora sujeitámos esta planta a um stress de desidratação: os tipos inatos não ficaram em muito bom estado. Pelo contrário, os transgénicos respondem ao stress, mas não ficam tão mal como os outros.

Poderia dizer-se que tivemos sorte, ou que o tabaco é peculiar por qualquer razão. Assim, em colaboração com colegas da Universidade de Cornell, clonámos esse gene da cevada no arroz, uma vez que a cevada e o arroz são bastante parecidos. Estudámos duas respostas ao stress: à seca (desidratação) e ao cloreto de sódio (alto grau de salinidade). Observámos o tipo inato (o controlo) e duas linhas de arroz transgénico. Para ambas as formas de stress, o tipo transgénico comportou-se muito melhor. Depois repetimos a experiência com trigo. Com o trigo os resultados foram similares.

Assim, introduzindo apenas um gene, mudando o promotor e o comutador, fomos capazes de melhorar drasticamente a resistência das plantas ao stress.

Avancemos mais uma etapa. Estamos ainda a falar do modo como a biotecnologia pode ser amiga do ambiente e a discutir a maneira de evitar polui-lo. Mas, e se queremos não apenas sobreviver no ambiente, mas melhorá-lo? Isto é um conceito novo chamado protecção vital. Usamos plantas para limpar o ambiente! Este conceito tem sido muito bem sucedido em ambientes de estufa, estando em curso os testes no campo.

Dou um bom exemplo: como há iões de mercúrio por todo o lado, fala-se hoje muito do chamado envenenamento por mercúrio. Há três formas de mercúrio, mas a forma mais vulgar é o $\mathrm{Hg}^{2+}$. $\mathrm{O}$ mercúrio elementar não é muito recomendável, mas, ainda assim, é menos prejudicial que o $\mathrm{Hg}^{2+}$, que é extremamente tóxico. Acontece que nas bactérias existem duas enzimas que conseguem reduzir o ião $\mathrm{Hg}^{2+}$ a mercúrio elementar. $\mathrm{Na}$ Universidade da Geórgia foram clonados os genes para aquelas duas enzimas. A hipótese é que as plantas expressando os redutores bacteriais de iões de mercúrio possam ser usadas para extrair o mercúrio iónico no solo e na água contaminada, desintoxicando-os.

Os cientistas introduziram esses genes em plantas. A planta de teste, a Ambidopsis, é fácil de manipular. Se colocarmos genes do ião de mercúrio na Ambidopsis, esta crescerá mesmo na presença de mercúrio. Pelo contrário, a planta de controlo acaba por morrer.

Agora examinemos um outro caso: o tabaco, que é outra planta fácil de manipular. Consideremos a planta de tabaco em tipos diferentes de solo, contendo tipos diferentes de compostos orgânicos, incluindo vários elementos tóxicos (entre os quais mercúrio). Se não houver mercúrio, 
todas as plantas crescerão; se houver mercúrio com uma concentração de 100 ppm, o tipo inato não crescerá; se houver iões de mercúrio, a planta com genes redutores do mercúrio ainda crescerá. Mas, se aumentarmos o mercúrio para concentrações muito elevadas, digamos acima de 500 ppm, todas as plantas morrerão.

Este caso mostra que podemos melhorar a resistência ao mercúrio em plantas introduzindo nelas dois genes bacterianos; elas não apenas sobrevivem para baixas concentrações de mercúrio como extraem iões de mercúrio, reduzindo-o a mercúrio elementar. Estamos a substituir uma forma de mercúrio altamente tóxica por outra que é apenas semi-tóxica - não é o ideal, mas mesmo assim é preferível. Ainda estão a ser realizadas experiências neste domínio, pelo que ainda não se pode vender este tipo de planta. Contudo trata-se de um conceito novo que não é apoiado por nenhuma empresa. As empresas não querem saber destes processos. Os governos, pelo contrário, estão em geral interessados porque se trata de ensaiar uma abordagem nova de combate à poluição.

$\mathrm{O}$ último assunto de que quero falar é da chamada agricultura molecular. O princípio desta agricultura é que as plantas não servem apenas para dar alimento e fibras. Uma vez que podemos usar ADN recombinante de um modo bastante flexível, podemos usá-lo para introduzir genes estranhos em plantas e obrigá-las a produzir algumas proteínas úteis.

Neste caso temos um promotor de plantas que dirige a expressão da sequência codificada para uma proteína animal. Depois introduzimos este ADN recombinante em plantas, produzindo estas proteínas animais, bacterianas ou outras.

O primeiro exemplo é novamente muito drástico: a produção de plásticos biodegradáveis em plantas. Isto era quase impensável há pouco tempo. Acontece que certas bactérias produzem um composto particular chamado poli-hidroxibutirato. Este é basicamente um polímero baseado no butirato, e o butirato é um composto muito simples (tem quatro carbonos). O composto pode ser facilmente produzido nestas bactérias porque elas têm duas enzimas diferentes que podem converter acetato de acetilo nesta espécie. Este acetato é um metabolito muito comum para a síntese de lípidos. Assim pode converter-se uma síntese intermédia de lípidos neste composto semiplástico. No entanto, este tipo de bactérias não é facilmente cultivável e não podemos usar facilmente o fermentador. A ideia é então introduzir em plantas os genes que codificam as duas enzimas existentes nas bactérias e controlar o seu funcionamento pela actividade do interruptor molecular das plantas (o promotor), de modo que a planta transgénica possa produzir poli-hidroxibutirano. 
As plantas modificadas evidenciam a presença de poli-hidroxibutirato. Esta substância é biodegradável porque se trata de um composto biológico natural; assim, pode degradar-se em sistemas biológicos. Como controlo, podemos usar uma garrafa comum de plástico. Comercialmente o processo tem difícil viabilidade porque, especialmente nos países pobres, as pessoas preferem comprar os produtos mais baratos a outros mais caros, embora mais ecológicos. Quando as disponibilidades financeiras mínimas das famílias não estão garantidas, as pessoas não percebem porque hão-de gastar mais dinheiro para proteger o ambiente. No entanto, nos países desenvolvidos, a utilização do poli-hidroxibutirato produzido por plantas transgénicas pode em breve vir a tornar-se realidade.

Ainda tenho mais dois exemplos. O primeiro tem a ver com a questão da saúde. De cada vez que comemos alguma coisa o nosso sistema imunitário começa a desenvolver anticorpos de protecção. Se colocarmos um antigénio nos alimentos que ingerimos, o nosso sistema imunitário produzirá anticorpos. Portanto, quando surge um patogene real, os respectivos anticorpos já estão preparados e o organismo pode defender-se de forma mais eficiente e pronta. Este é um meio muito fácil de imunização. Claro que podemos sempre injectar alguma coisa no nosso corpo, mas isso é uma medida muito drástica.

Porque não produzimos então uma planta transgénica que sirva de alimento, uma proteína - uma só uma proteína - de uma bactéria que geralmente queiramos ver longe de nós? É apenas uma proteína, não é uma bactéria completa - uma proteína de uma bactéria não causa nenhum problema, ao contrário de uma bactéria inteira. Isolamos o gene que codifica a proteína da superfície desta bactéria, introduzimos esse gene em plantas e a planta produz a proteína. Quando comemos essa planta transgénica produzimos anticorpos contra a tal proteína particular. Quando a bactéria real entrar no organismo, tem logo à sua espera os anticorpos que rapidamente a eliminam.

O exemplo seguinte é um trabalho de um colega meu na Universidade de Washington. Ele isolou o antigénio da superfície da bactéria oral que normalmente provoca a degradação dos dentes. Todos nós sofremos em maior ou menor grau de degradação dos dentes causada por bactérias. Normalmente, um bebé, quando nasce, não traz bactérias na boca. Mas, mais tarde, em virtude de beijos e outras actividades, certas bactérias entram na sua boca, pelo que a criança começa a ter problemas dentários. Assim, queremos isolar o gene bacteriano (o que já foi feito) e colocá-lo em plantas que o bebé normalmente coma. O seu organismo desenvolverá então os anticorpos antes de encontrar a bactéria. Quando se iniciar a deterioração dos dentes, os anticorpos estarão à espera, sendo provável 
que essa deterioração não avance. Este processo já foi testado com sucesso em animais.

Há outro exemplo, que não vou pormenorizar. $\mathrm{O}$ antigénio da hepatite B foi desenvolvido na banana, um fruto muito comum na Ásia e na América do Sul. Se colocarmos este antigénio da hepatite na banana, quem a comer desenvolverá certos anticorpos. O vírus que aparecer terá de enfrentar os respectivos anticorpos. Isto está também actualmente a ser testado!

Derradeiro exemplo: porque não produzir anticorpos directamente em vez de produzir antigénios? Um artigo da Nature de há cerca de dez anos descreve um tal processo. Produzir anticorpos em plantas é relativamente fácil, graças mais uma vez à tecnologia do $\mathrm{ADN}$ recombinante. $\mathrm{Na}$ realidade podemos usar plantas para fazer uma grande variedade de coisas, em vez de nos limitarmos a seguir a linha de pensamento da agricultura tradicional.

Resumindo, o meu primeiro ponto é que a biotecnologia acelera alterações genéticas e aumenta também a diversidade. E isto acontece porque o $\mathrm{ADN}$ recombinante pode criar novos tipos de plantas sem esperar que a natureza o faça.

O segundo ponto, mais importante, é que biotecnologia permite uma melhor administração de recursos biológicos. Isto nada tem a ver com o $\mathrm{ADN}$ recombinante. Quando se corta o $\mathrm{ADN}$ aos pedaços, não se obtém $\mathrm{ADN}$ recombinante porque não há qualquer recombinação. Assim, não há neste caso que estar preocupado com o $\mathrm{ADN}$ recombinante: trata-se apenas de biotecnologia.

O terceiro ponto é que a biotecnologia na agricultura pode ser amiga do ambiente, se se proceder com suficiente cuidado.

As plantas são muito mais interessantes do que se poderia pensar. Com elas podemos fazer coisas curiosas e úteis. Olhemos, portanto, para a biotecnologia numa perspectiva equilibrada. A biotecnologia pode trazer-nos muitos benefícios. Claro que, mal usada, pode também originar maus resultados, mas esta é uma questão comum a todas as tecnologias. A tecnologia é sempre uma espada de dois gumes... 
(Página deixada propositadamente em branco) 
 \\ A palavra "fronteiras" pode ser tomada em} diferentes sentidos. Pode referir-se aos limites, necessariamente provisórios, entre o conhecido e o desconhecido, ou aos limites entre o possivel e o impossivel, e, dentro do possivel, entre o desejável e 0 indesejável. Fronteiras podem também ser as delimitações, nem sempre nítidas, entre ciência e não-ciência, e dentro da ciência, entre as várias disciplinas. Quais são então as fronteiras da ciência?

Neste livro, a resposta a esta pergunta é dada, segundo as mais diferentes perspectivas, por um conjunto notável de personalidades, cientistas ou não, entre as quais se contam três Prémios Nobel.

Rui Fausto, Carlos fiolhais e JoÃo Fillipe Queiró são, respectivamente, professores de Química, Física e Matemática na Faculdade de Ciências e Tecnologia da Universidade de Coimbra. 